\title{
Effect of Garlic, Zinc Oxide and CTAB Nanocomposite against Hepatocellular Carcinoma in Vitro and Rats on Cell Cycle, Caspase 3and DNA Fragmentation Percent \\ Omayma.A.R.Abou Zaid ${ }^{1}$, M.K.Mahfouz ${ }^{1}$, A.A.M.Elwakil ${ }^{1}$ and A.M.Badawi ${ }^{2}$ \\ ${ }^{1}$ Biochemistry Dept., Faculty of Veterinary Medicine, Benha Univ., Benha, Egypt \\ ${ }^{2}$ Egyptian Petroleum Research Institute, Egypt
}

\begin{abstract}
Nanoparticles plans to overcome the problems related to human diseases at the nanoscale level and making significant contributions to the improvement of new approaches of drug delivery in cancer and can provide a stage for combined therapeutics with subsequent monitoring of response. (Garlic and zinc oxide ( $\mathrm{ZnO}$ ) coated by cetyl trimethyl ammonium bromide) nanoparticles have been applying treatment action against hepatocellular carcinoma in vitro and in vivo which was done on 60 rats and was divided into four groups, each groups have (15 rats), (Group 1) NTBR (Negative control) group; (Group 2) (TBR) HCC (DEN) group (Group 3) (TBRT) (garlic / Zinc oxide / CTAB) nanoparticles; (Group 4) (TBRT Doxorubicin). The changes of the biochemical indices of serum, and the levels of the Cell cycle, Caspase 3and DNA fragmentation percent of liver were analyzed to evaluate the treatment activity. At the end of the study (10 weeks), DEN induced elevation of the serum biochemical indices alanine aminotransferase, aspartate aminotransferase, alkaline phosphatase, gammaglutamyl transferase, Alpha feto-protein, (garlic/Zinc oxide/ CTAB) nanoparticles administration significantly inhibited the increase of the ALT, AST, ALP, GGT and AFP . The mechanistic studies demonstrated that (garlic/Zinc oxide/CTAB) nanoparticles counteracted DEN induced protein levels of Caspase 3and DNA fragmentation percent were significantly increased. We observed that nanocompsite have different effects on liver cell viability via killing cancer cells, while posing no effect on normal cells of the liver. The marked difference in cytotoxicity between cancer cells and normal cells suggests an exciting potential for nanocompsite as novel alternatives to hepatocellular carcinoma therapy.
\end{abstract}

Keywords: Garlic, Zinc oxide, CTAB, Nanoparticles, Cell cycle, Caspase 3and DNA fragmentation percent.

\section{Introduction}

Hepatocellular carcinoma $(\mathrm{HCC})$ is a major reason of human cancer death [1]. HCC commonly present in Asia and Africa, and its incidence rate is starting to increase in Western countries. Due to absence of effective biomarkers for diagnosis and prognosis, HCC is frequently found in late stages, when curative therapy approaches like resection, liver transplantation, radio frequency ablation (RFA), and transarterial chemoembolization (TACE) don't produce satisfactory clinical outcomes [2] Garlic has been demonstrated cytotoxicity against different cancer cells such as colon cancer, glioblastoma, and hepatocarcinoma cells by apoptosis and autophagy [3]. Oxidative stress conditions enhance the production of ROS resulting from a variety of stimuli and are proposed as one of the most important mechanisms for nano materials mediated toxicity [4]. Recent studies have proved that zinc oxide $(\mathrm{ZnO})$ nanoparticles can cause toxicity in different cell lines; oxidative stress is often hypothesized to be an important factor in cytotoxicity of $\mathrm{ZnO}$ nanoparticles [5]. Studies had indicated that $\mathrm{ZnO}$ nanoparticles could exert cytotoxicity on the liver and kidney cells in rat via induction of oxidative stress, DNA damage and apoptosis [6]. Anthracyclines remain the most widely prescribed and effective anticancer agents. Doxorubicin (DOX), an anthracycline anticancer drug of secondary metabolite of Streptomyces peucetius var. caesius, is widely used in several adult and pediatric cancers such as thyroid cancer, ovarian cancer, leukemia, lymphomas, liver cancer and breast cancer [7].

The aim of this study response the problems related to human diseases at the nanoscale level and making significant contributions to the improvement of new approaches of drug delivery in cancer and can provide a stage for combined therapeutics with subsequent monitoring.

\section{Materials and methods}

\subsection{Chemicals}

N-nitroso di-ethylamine DEN (purity 99\%) was purchased from Sigma Aldrich Company for Trading Chemicals, Medicines and Medical Appliances, Egypt. Tomex (Dry garlic powder): highly concentrated garlic powder prepared from organically grown garlic without use chemical fertilizer or pesticides. $\mathrm{ZnO}$ nanogard (purity $\sim 99 \%$ ) was manufactured by Sigma Chemical Co. (St. Louis, Mo, USA) and purchased from Schnelldorf, Germany through Alfa Acear, Egypt. CTAB (purity $~ 99 \%$ ) was manufactured by Sigma Chemical Co. (St. Louis, Mo, USA) and purchased from Schnelldorf, Germany through the Egyptian International Center for Import Cairo, Egypt. 
2.2 Preparations and measurements of garlic, zinc oxide, cetrammonium bromide complex nanoparticles

Preparation of Nanocomposite for biochemical investigation of antitumor activity as anticancer was prepared through the following methods.

Formulation of drug: Garlic (A) + Zinc oxide (B) + Cetrammonium bromide (C) were mixed together as follows:

$$
(\mathrm{A})=4 \&(\mathrm{~B})=2 \mathrm{~g} \&(\mathrm{C})=2 \mathrm{~g}
$$

The formula drug was mixed mechanically very well with the using vortex then both are grind to the nano sized particles using ball mill (nano system unit) at $200 \mathrm{rpm}$ for 10 hours.

\subsection{In vitro study (Cytotoxic assay)}

The antitumor effect and inhibitory concentration 50 (IC50) of this novel nanocompsite will be investigate against (HepG-2) (Hepatocellular Carcinoma Cell line).

\subsection{In vivo study}

A total number of 60 albino male rats 4 weeks old and weighting $100 \pm 10 \mathrm{~g}$ were used in the experimental investigation of this study. Rats were obtained from the Laboratory Animals Research Center, Faculty of Veterinary Medicine, Moshtohor, Benha University. Animals were housed in separate metal cages, (15 animals per cage), fresh and clean drinking water was supplied ad-libtium.

\subsection{Preparation and administration of dosage}

DEN: $20 \mathrm{mg}$ DEN was dissolved immediately previous to its use in $10 \mathrm{ml}$ of $\mathrm{NaCl}(0.9 \%$ normal saline) [8], that each $\mathrm{ml}$ was containing $2 \mathrm{mg}$ of DEN and was orally administered with dose of 20 $\mathrm{mg} / \mathrm{kg}$ b.wt., five times a week for 6 weeks [9]. (garlic/Zinc oxide/CTAB) nanoparticles mixture at a dose of $30 \mathrm{mg} / \mathrm{kg}$.b.w. dissolved in saline injected orally by stomach tube one time per day week for the end of experiment. Doxorubicin Received 33 $\mathrm{mg} / \mathrm{kg}$.b.w./ i.p dissolved in physiological saline once a week for 4 weeks) from time at tumor bearing rats $[10]$.

\subsection{Experimental design}

Sixty Rats were randomly divided into four main groups, each groups have (15 rats), placed in individual cages and classified as following: (Group 1) served as control normal group, (Group 2) served as induced hepatocellular carcinoma orally administered DEN for induction of hepatocellular carcinoma at a dose of $20 \mathrm{mg} / \mathrm{kg}$ b.w., five times a week for 6 weeks. (Group 3) served as treated group with (garlic/Zinc oxide/CTAB) nanoparticles were orally administered DEN with a dose of 20 $\mathrm{mg} / \mathrm{kg}$ b.w. Five times a week for 6 weeks, and subsequently treated with (garlic/Zinc oxide/CTAB) nanoparticles at a dose of $30 \mathrm{mg} / \mathrm{kg}$ b.w., one time per day for 4 weeks. (Group4) served as treated group with Doxorubicin were orally administered DEN with a dose of $20 \mathrm{mg} / \mathrm{kg}$ b.w., five times a week for 6 weeks, and subsequently treated with doxorubicin as a reference drug with a dose of $33 \mathrm{mg} / \mathrm{Kg}$.b.w./i.p dissolved in physiological saline once a week for 4 weeks.

\subsection{Sampling}

At the end of the experimental period, rats were fasted overnight, blood samples were taken from retro-arbitral plexus. The blood samples were collected in dry, clean test tubes and allowed to clot for $30 \mathrm{~min}$ and serum was separated by centrifugation at $3000 \mathrm{rpm}$ for $15 \mathrm{~min}$ at $4^{\circ} \mathrm{C}$. The serum was separated by automatic pipette and received in dry sterile tubes, processed directly for ALT, AST, ALP, GGT and AFP. Liver tissues were divided into appropriate portions, homogenized with a glass homogenizer in 9 volume of ice-cold $0.05 \mathrm{mM}$ potassium phosphate buffer $(\mathrm{pH}$ 7.4) to make $10 \%$ homogenates. The homogenates were centrifuged at 6000 r.p.m for 15 minutes at $4^{\circ} \mathrm{C}$ then the resultant supernatant were used for the determination of the following molecular analysis: cell cycle, Caspase 3and DNA fragmentation percent.

\subsection{Serum biochemical assays}

He levels of serum alanine aminotransferase (ALT) and aspartate aminotransferase (AST) were determined according to [11], gammaglutamyl transferase (GGT) was determined according to [12] and alkaline phosphatase (ALP) was determined according to [13].Alpha fetoprotein (AFP) concentration was determined in serum using ELISA Kit for Alpha fetoprotein: Ratus norvegicus (Rat) (DesigDEN by Cloud-Clone Corp., assembled by Uscn Life Science Inc. ISO9001:2008: ISO13485:2003, Catalog Number: MBS724171 according to the manufacturer's instruction.

\subsection{Molecular analysis}

Flow cytometric analysis for determination cell cycle in liver tissue prepared according to [14]. Flow cytometric analysis for determination Caspase $3 \%$ in liver tissue prepared according to [15] and Flow cytometric analysis for determination DNA fragmentation $\%$ in liver tissue prepared according to [16].

\subsection{Statistical analysis}

The results were expressed as mean $( \pm$ S.E. $)$ and statistical significance was evaluated by one way ANOVA using SPSS (version 22) program followed by the post hoc test, least significant difference (LSD). Values were considered statistically significant when $\mathrm{p}<0.05$. 


\section{Results and discussion}

3.1 Evaluation of cytotoxicity of (Garlic, Zinc oxide, cetrammonium bromide) Nanoparticles against HepG-2 cell line

\section{Comment:}

Inhibitory activity against Hepatocellular carcinoma cells was detected under these experimental conditions with IC50 $=3.61 \mu \mathrm{g} / \mathrm{well}$.

\subsection{Liver molecular assays}

\subsection{Biochemical parameters in serum} 3.4 Caspase-3 \%and DNA fragmentation \%

\section{Discussion}

Hepatocellular carcinoma (HCC), which represents $80 \%$ of primary liver cancers, is related chiefly with inflammation damaged livers resulting from viral hepatitis infections (hepatitis B or C), or from cirrhosis because of chronic alcoholism [17]. Nitrosamines are chemical substance having the chemical structure $\mathrm{R}^{1} \mathrm{~N}\left(-\mathrm{R}^{2}\right)-\mathrm{N}=\mathrm{O}$, it is the most carcinogenic chemical compound. It is inter in the manufacture of some cosmetics, pesticides, and in most rubber products. In a wide variety of animals, nitrosamines can cause cancers, this feature suggests they may also be carcinogenic in human; it is often used as a carcinogenic reagent in liver [18].

Our result in table (1) and fig (1) demonstrated that decrease in cell viability of HepG-2 Cell Line after treatment with Nanocomposite of the garlic, $\mathrm{ZnO}$ nanoparticles and CTAB confirms that synthesized Nanocomposite can have an anticancer property \& also was found to be highly effective and to provide reliable results.

Anumber of studies have demonstrated the chemopreventive activity of garlic by using different garlic preparations including fresh garlic extract, aged garlic, garlic oil and a number of organosulfur compounds derived from garlic. The chemopreventive activity has been attributed to the presence of organosulfur compounds in garlic [19]. Belloir et al. [20] assessed the antigenotoxic potential of purified garlic compounds like allicin, DAS, DADS, SAC and AM in the human hepatoma cell line HepG2 and found them to protect human hepatic cells against the genotoxicity induced by indirect and direct acting genotoxic agents primarily by the inhibition of CYP enzymes and induction of phase II enzymes [21]. The previous studies also demonstrated that $\mathrm{ZnO}$ nanoparticles could apply cytotoxicity on sensitive and drugresistant hepatocellular carcinoma SMMC-7721 cell line in vitro [5]. Selective killing of cancer cells by $\mathrm{ZnO}$ NPs may be of important clinical interest, as one of the greatest challenges facing cancer chemotherapy is the incapability of anticancer drugs to effectively distinguish between normal and cancer cells. The shape of NPs also plays a significant role in the killing of cancer cells [22].
As shown in Table (2) there is a significant increase in serum ALT, AST, ALP, GGT and AFP were observed in DEN group when compared with those in control group, treatment with (garlic/Zinc oxide/CTAB) nanoparticles and Doxorubicin in DEN induced hepatocellular carcinoma in rats exhibited a significant decrease when compared with hepatocellular carcinoma control group .The soluble hepatic enzyme like ALT, AST, ALP of blood serum have been considered as marker for hepatic dysfunction and damage and thus causing change in liver function the hepatic cell damage exhibit good correlation with these enzyme leakage [23]. The elevated in GGT activity in carcinogenic rats may be explained on the basis of its diffusion from the cell membrane into the circulation suggesting damage in cellular membrane integrity by DEN [24], a number of studies have shown that hepatic metabolism of DEN generate ROS resulting in oxidative stress and cell damage [25] which give an extra support of the elevated liver function enzyme activities following hepatic injury.

The obtained data of the liver cell cycle demonstrated in Table (3) and Fig (2) revealed that a significant increase in liver sub G0\% percent in DEN group (TBR) when compared with control normal group (NTBR) and there was a significant decrease in liver sub G0\% percent and cell count $\%$ in $\mathrm{S}$ phase in TBRT (garlic/Zinc oxide/CTAB) and TBRT (DOX) when compared with DEN (TBR) group.

Furthermore there was a significant increase in liver G2M \% and sub G1 apoptosis in TBRT (garlic/Zinc oxide/CTAB) and TBRT (DOX) when compared with DEN (TBR) group.

Our result in Table (4) and Fig $(3,4)$ demonstrated that Caspase $3 \%$ in liver tissue showed significant decreases in DEN group, as compared with the control group. Also there is significant increases in DNA fragmentation \% in liver tissue were noticed in DEN group. In contrast, Garlic nanoparticles administration markedly increased Caspase 3 level and DNA fragmentation percent TBRT (garlic/Zinc oxide/CTAB) and TBRT (DOX) when compared with DEN (TBR) group.

Garlic is a multi-component pioneer food that shows induction of oncogenesis, tumorigenesis, induction of cell cycle arrest and apoptosis, cancer cell proliferation and invasion which can be used as an improved tool in cancer treatment. Garlic and its components have following anticancer activities. Diallyl sulfide promote cell cycle arrest through the p53 expression and trigger induction of apoptosis via caspase and mitochondria dependent signaling pathways in human cervical cancer $\mathrm{Ca}$ Ski cells $[26,27]$. It induces apoptosis in human breast cancer cells [28] and induces cell cycle arrest in prostate cancer cell and apoptosis induction in cancer cells. It also controls unregulated cell 
division in human cancer cells and influence cell cycle dysregulation and control signal transduction pathways. Also, garlic derived organosulfur compounds; mostly DATS, DADS, ajoene, and SAMC induce cell cycle arrest in cancer cells in culture experiments [29]. A number of lines of evidences recommend that cancer cells treated with OSC can lead to the arrest in G2/M phase of the cell cycle during modulating the expressions or activities of cyclins, cyclindependent kinases (Cdks), signaling molecules and histones [30].

CTAB has a smart structure with a positively charged polar head and a nonpolar hydrophobic tail.
The trait of the amphipathic molecule causes the disturbance of lipid bilayers and the increase in cell membrane permeability, because of nanoscale whole formation by the quaternary ammonium cation attachment on to the membrane. The increase of cell membrane permeability is a pivotal event in apoptosis initiation [2]. Two main apoptosis pathways have been defined in mammalian cells, one receiving and processing extracellular death inducing signals (such as Fas ligand/Fas receptor), and the other sensing and integrating a variety of intrinsic signals (for example the mitochondria dependent pathway).

Table (1) Evaluation of cytotoxicity with nanocmposite (CTAB coated Garlic ZnO) Against Hepatocellular Carcinoma Cells (HepG-2 Cell Line)

\begin{tabular}{lc}
\hline Sample conc.( $\boldsymbol{\mu g}$ /well) & Viability \% \\
\hline 50 & 18.72 \\
25 & 25.96 \\
12.5 & 34.19 \\
6.25 & 40.85 \\
3.125 & 51.68 \\
1.56 & 62.43 \\
0.78 & 70.89 \\
0.39 & 78.47 \\
0 & 100.00 \\
\hline
\end{tabular}

Table (2) The effect of nanocomposites (garlic/Zinc oxide/CTAB) on ALT, AST, ALP, GGT and AFP of normal and DEN induced in serum hepatocellular carcinoma in male rats

\begin{tabular}{lccccc}
\hline Group & ALT (U/L) & AST (U/L) & ALP (U/L) & GGT (U/L) & AFP (Pg/ml) \\
\hline NTBR & $39.40 \pm 2.89^{\mathrm{b}}$ & $52.60 \pm 3.70^{\mathrm{d}}$ & $170.60 \pm 6.00^{\mathrm{c}}$ & $46.8 \pm 4.12^{\mathrm{c}}$ & $46.00 \pm 2.70^{\mathrm{c}}$ \\
TBR & $198.60 \pm 57.54^{\mathrm{a}}$ & $145.00 \pm 3.56^{\mathrm{a}}$ & $279.80 \pm 3.54^{\mathrm{a}}$ & $108.6 \pm 4.26^{\mathrm{a}}$ & $97.00 \pm 4.28^{\mathrm{a}}$ \\
TBR (nanoparticles) & $87.40 \pm 2.77 \mathrm{~b}$ & $90.80 \pm 2.33 \mathrm{~b}$ & $212.20 \pm 3.32 \mathrm{~b}$ & $65.8 \pm 3.68 \mathrm{~b}$ & $66.00 \pm 3.90 \mathrm{~b}$ \\
TBR (DOX) & $70.80 \pm 2.48 \mathrm{~b}$ & $82.40 \pm 2.52 \mathrm{bc}$ & $194.80 \pm 5.76 \mathrm{~b}$ & $64.6 \pm 2.18 \mathrm{~b}$ & $68.40 \pm 2.38 \mathrm{~b}$ \\
LSD at 0.05 & 69.01 & 15.60 & 17.95 & 11.17 & 9.24 \\
\hline
\end{tabular}

Table (3) The effect of nanocomposites (garlic/Zinc oxide/CTAB) on sub G0\%, cell count \% in S phase, G2M $\%$ and sub G1 apoptosis in tissue of normal and DEN-induced hepatocellular carcinoma in male rats

\begin{tabular}{lcccc}
\hline Group & $\begin{array}{c}\text { Percent of count } \\
\text { of G0 In liver } \\
\text { tissue (\%) }\end{array}$ & $\begin{array}{c}\text { Percent of count } \\
\text { of S phase in liver } \\
\text { tissue (\%) }\end{array}$ & $\begin{array}{c}\text { Percent of count } \\
\text { of G2M in liver } \\
\text { tissue (\%) }\end{array}$ & $\begin{array}{c}\text { Percent of } \\
\text { Apoptosis in liver } \\
\text { tissue (\%) }\end{array}$ \\
\hline NTBR & $12.40 \pm 0.57^{\mathrm{b}}$ & $75.37 \pm 0.55^{\mathrm{a}}$ & $6.10 \pm 0.61^{\mathrm{e}}$ & $3.70 \pm 0.70^{\mathrm{d}}$ \\
TBR & $16.43 \pm 0.75^{\mathrm{a}}$ & $70.53 \pm 0.48^{\mathrm{b}}$ & $5.13 \pm 0.64^{\mathrm{e}}$ & $3.30 \pm 0.72^{\mathrm{d}}$ \\
TBR (nanoparticles) & $3.67 \pm 0.59^{\mathrm{e}}$ & $65.37 \pm 0.42^{\mathrm{c}}$ & $23.33 \pm 0.72^{\mathrm{b}}$ & $10.33 \pm 0.56^{\mathrm{b}}$ \\
TBR (DOX) & $5.27 \pm 0.67^{\mathrm{d}}$ & $51.50 \pm 0.72^{\mathrm{d}}$ & $29.37 \pm 0.47^{\mathrm{a}}$ & $16.40 \pm 0.67^{\mathrm{a}}$ \\
LSD at 0.05 & 1.52 & 1.45 & 1.49 & 1.51 \\
\hline
\end{tabular}

Table (4) T The effect of nanocomposites (garlic/Zinc oxide/CTAB) on Caspase-3 \%and DNA fragmentation \% in tissue of normal and DEN-induced hepatocellular carcinoma in male rats

\begin{tabular}{lcc}
\hline Group & $\begin{array}{c}\text { Percent of count of Caspase- } \\
\mathbf{3}(\%)\end{array}$ & $\begin{array}{c}\text { Percent of count of DNA } \\
\text { fragmentation (\%) }\end{array}$ \\
\hline NTBR & $67.13 \pm 3.43^{\mathrm{a}}$ & $4.6^{\mathrm{d}}$ \\
TBR & $46.33 \pm 0.42^{\mathrm{d}}$ & $13.7^{\mathrm{c}}$ \\
TBR (nanoparticles) & $60.57 \pm 3.09^{\mathrm{b}}$ & $27.2^{\mathrm{b}}$ \\
TBR (DOX) & $60.63 \pm 2.10^{\mathrm{b}}$ & $46.5^{\mathrm{a}}$ \\
LSD at 0.05 & 6.01 & 6.01 \\
\hline
\end{tabular}




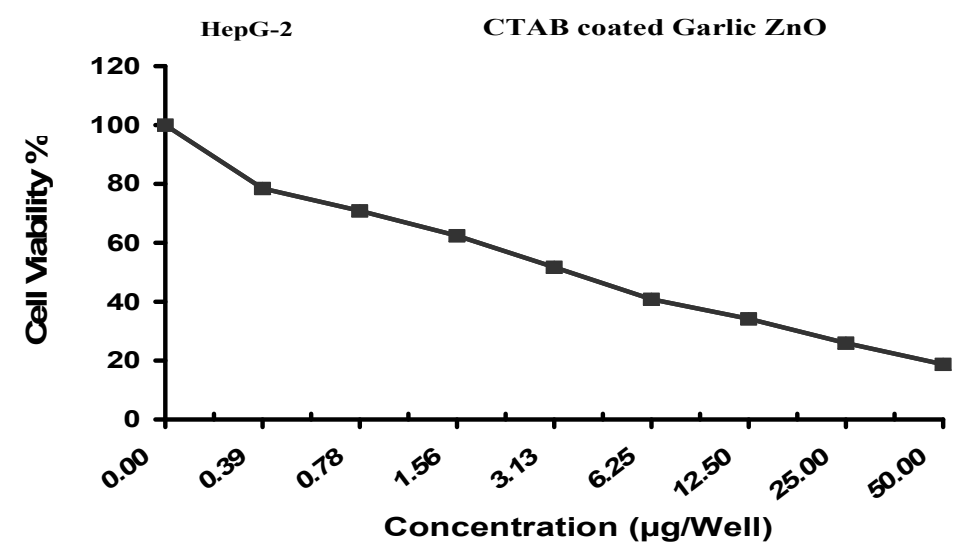

Fig (1) Evaluation of cytotoxicity with nanocmposite (CTAB coated Garlic ZnO) Against Hepatocellular Carcinoma Cells (HepG-2 Cell Line)

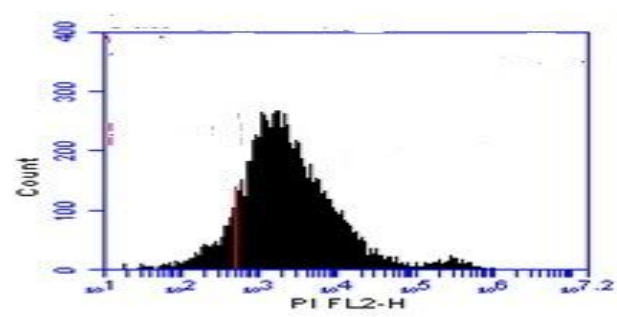

NTBR

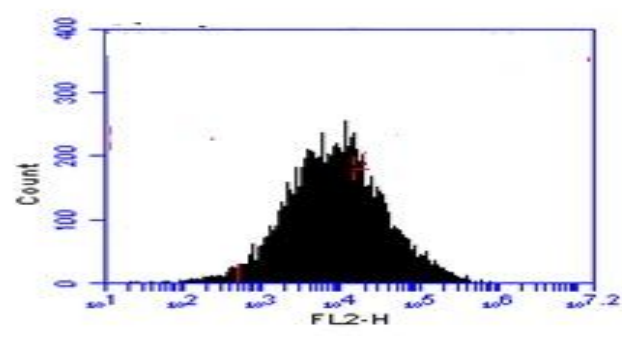

TBRT (nanoparticles)

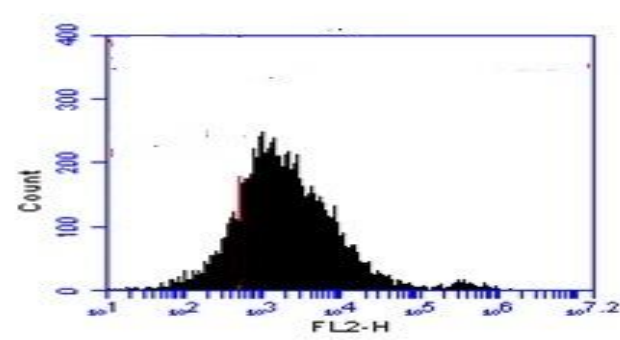

TBR

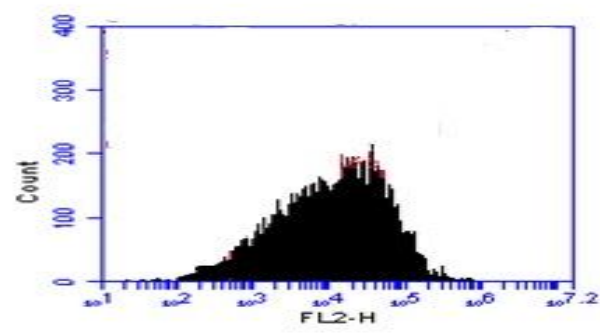

TBRT (DOX)

Fig (2) Flow cytometry charts of liver cell cycle of studies group $\mathrm{M} 1=$ sub $\mathrm{G} 1$ apoptosis $\quad \mathrm{M} 2=\mathrm{G} 0 / 1$ $\mathrm{M} 3=\mathrm{S}$ phase

$\mathrm{M} 4=\mathrm{G} 2 / \mathrm{m}$
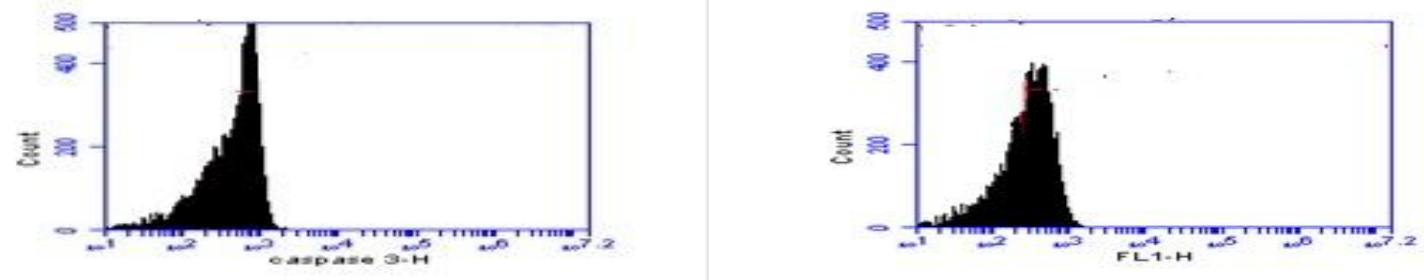

NTBR

TBR

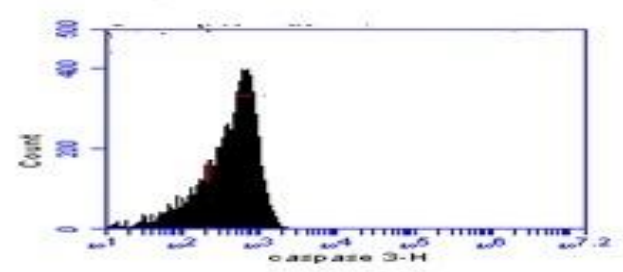

TBRT (garlic/Zinc oxide/CTAB)

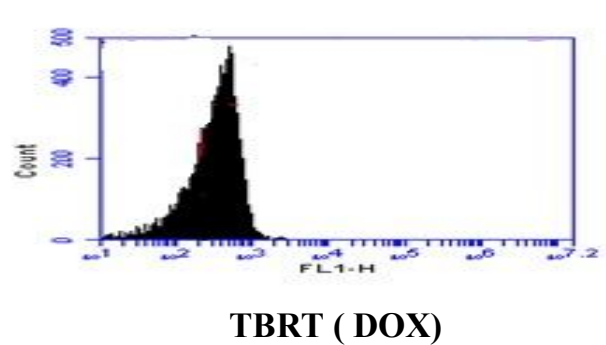

Fig (3) Flow cytometry charts ofliverCaspase-3\%of studies group 


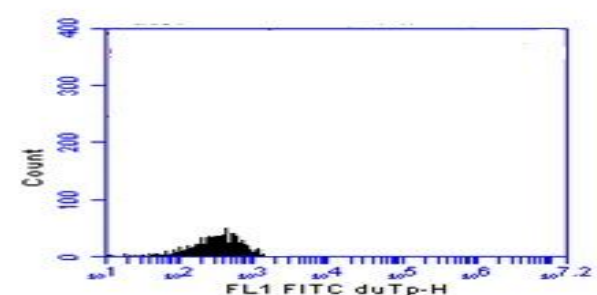

NTBR

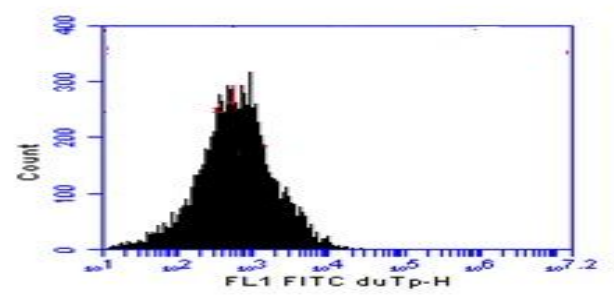

TBRT (garlic/Zinc oxide/CTAB)

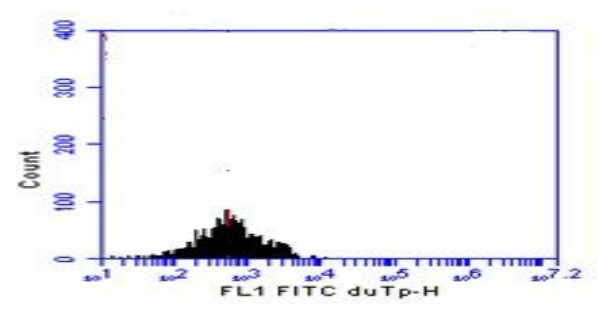

TBR

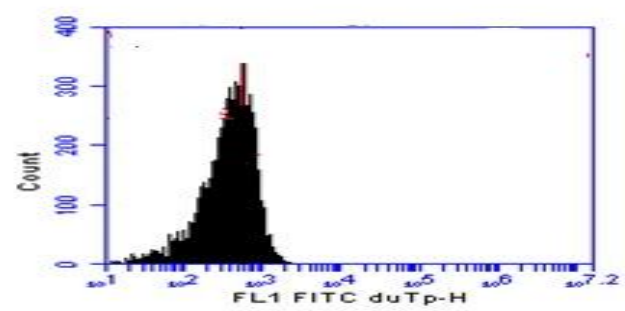

TBRT ( DOX)

Fig (4) Flow cytometry charts of liver DNA Fragmentation \%of studies group.

\section{Conclusion}

In the light of the foregoing results, it can be concluded that:

1. DEN play a role in the development of hepatocellular carcinoma and this effect may be mediated by inhibition of Casepase - 3 resulting in inhibition of apoptosis and cause carcinogenesis.

2. Garlic/Zinc oxide/CTAB Nancomposite attenuates carcinogenic effects of DEN on rat liver and reverses DEN induced suppression of caspases3 and increase DNA fragmentation percent and induced cell cycle arrests. Collectively, these observations suggested that novel synthetic Nano composite may potentially presents new hope for the development of hepatocellular carcinoma chemotherapy.

\section{References}

[1] P.Fitzmorris, M.Shoreibah, B.S.Anand and A.K.Singal. Management of hepatocellular carcinoma. Journal of cancer research and clinical oncology, vol.141(5), pp.861-876, 2015.

[2] L.Zhang, J.Han, H.Wu, X.Liang, J.Zhang, J.Li and J.Yu, The association of HMGB1 expression with clinicopathological significance and prognosis in hepatocellular carcinoma: a meta-analysis and literature review. PloS one, vol.9(10), p. e110626, 2014.

[3] Y.L.Chu, C.T.Ho, J.G.Chung, R.Raghu, Y.C.Lo and L.Y.Sheen, Allicin induces antihuman liver cancer cells through the p53 gene modulating apoptosis and autophagy. Journal of agricultural and food chemistry, vol.61(41), pp.9839-9848, 2013.
[4] M.Ahamed, M.J.Akhtar, M.Raja, I.Ahmad, M.K.J.Siddiqui, M.S.AlSalhi, et al. , Zinc oxide nanorod induced apoptosis via p53, bax/bcl-2 and survivin pathways in human lung cancer cells: role of oxidative stress. Nanomedicine: NBM., vol.7, pp.904-913, 2011.

[5] D.Guo, H.Bi, B.Liu, Q.Wu, D.Wang, and Y.Cui, Reactive oxygen species-induced cytotoxic effects of zinc oxide nanoparticles in rat retinal ganglion cells. Toxicology in Vitro, vol.27(2), pp.731-738, 2013.

[6] P.Li, S.S.Wang, H.Liu, N.Li, M.A.McNutt, G.Li and HG.Ding, Elevated serum alpha fetoprotein levels promote pathological progression of hepatocellular carcinoma. World J Gastroenterol., vol.17, pp.4563-4571, 2011.

[7] W.G.Hozayen and H.S.Abou Seif, Protective effects of rutin and hesperidin against doxorubicin-induced lipodystrophy and cardiotoxicity in albino rats," Journal of American Science, vol.7, pp.765-775, 2011.

[8] B.N.Singh, B.R.Singh, B.K.Sarma and HB.Singh, Potential chemoprevention of Nnitrosodiethylamine-induced hepatocarcinogenesis by polyphenolics from Acacia nilotica bark. Chem Biol Interact. Vol.181, pp.20-28, 2009.

[9] H.A.Darwish and N.A.El-Boghdady, Possible involvement of oxidative stress in diethylnitrosamine induced hepatocarcinogenesis chemopreventive effect of curcumin. J. Food Biochem, vol.37, pp.353-61, 2011.

[10]P.Padmavathi, P.Senthilnathan, D.Chodon and D.Sakthisekaran, Therapeutic effect of 
paclitaxel and propolis on lipid peroxidation andantioxidant system in 7, 12 dimethyl benz (a) anthracene-inducedbreast cancer in female Sprague Dawley rats. Life Sciences, vol.78, pp.2820-2825, 2006.

[11] C.Murray, Losing Ground: American Social Policy, 1950-1980. New York: Basic Books, 1984.

[12]G.Szasz, A kinetic photometric method for serum $\gamma$-glutamyltransferase J. Clin Chem, vol.15, pp.124-136, 1969.

[13]N.W.Tietz, C.A.Burtis, P.Ducan, K.Ervin, C.J.Petitclera, A.D.Rinker, D.Shney and E.R.Zygowicz, A reference method for measurement of alkaline phosphatase activity in human serum. Clin. Chem., vol.29, pp.751$761,1983$.

[14]B.Tribukait, Flow cytometry in surgical pathology of tumors of the genitor-urinary tract luikoss LG, Coleman DV, eds. Adzances in clinical cytology. Vol.2, pp.89-163, 1984.

[15]P.N.Dean and J.H.Jett, Brife note: mathematical analysis of DNA distributions derived from flow microfluorometry. J. Cell. Biol., vol.60, pp.523-535, 1974.

[16]R.Sharma, J.Masaki and A.Agarwal, Sperm DNA fragmentation analysis using the TUNEL assay. Spermatogenesis: Methods and Protocols, pp.121-136, 2013.

[17]J.Hong, H.Wang, G.Shen, D.Lin, Y.Lin, N.Ye and C.Meng, Recombinant soluble gp130 protein reduces DEN-induced primary hepatocellular carcinoma in mice. Scientific reports, vol.6, pp.24397, 2016.

[18]G.S.Bhakuni, O.Bedi, J.Bariwal, R.Deshmukh and P.Kumar, Animal models of hepatotoxicity Inflammation Research vol.65(1), pp.13-24, 2016.

[19]M.Thomson and M.Ali, Garlic [Allium sativum]: A Review of its Potential Use as an Anti-Cancer Agent Current Cancer Drug Targets, vol.3(1), pp.67-81, 2003.

[20]C.Belloir, V.Singh, C.Daurat, M.H.Siess and A.M.Le Bon, Protective effects of garlic sulfur compounds against DNA damage induced by direct- and indirect-acting genotoxic agents in HepG2 cells. Food and Chemical Toxicology vol.44, pp.827-834, 2006.

[21]D.Tong, H.Qu, X.Meng, Y.Jiang, D.Liu, S.Ye, H.Chen, Y.Jin, S.Fu and J.Geng, Sallylmercaptocysteine promotes MAPK inhibitor-induced apoptosis by activating the TGF- $\beta$ signaling pathway in cancer cells. Oncol Rep, vol.32, pp.1124-1132, 2014.

[22]M.H.Abdolmohammadi, F.Fallahian, Z.Fakhroueian, M.Kamalian, P.Keyhanvar,
F.M.Harsini and A.Shafiekhani, Application of new $\mathrm{ZnO}$ nanoformulation and $\mathrm{Ag} / \mathrm{Fe} / \mathrm{ZnO}$ nanocomposites as water-based nanofluids to consider in vitro cytotoxic effects against MCF-7 breast cancer cells. Artificial Cells, Nanomedicine, and Biotechnology, pp.1-9, 2017.

[23]G.E.El-Desoky, A.Abdel-Ghaffar, Z.A.AlOthman, M.A.Habila, Y.A.Al-Sheikh, H.K.Ghneim and M.A.M.Aboul-Soud, Curcumin protects against tartrazine-mediated oxidative stress and hepatotoxicity in male rats. European review for medical and pharmacological sciences, vol.21(3), pp.635645, 2017.

[24]S.S.Al-Rejaie, A.M.Aleisa, and A.A.Al-Yahya, Progression of diethyl nitrosamine-induced hepatic carcinogenesis in carnitine-depleted rats. World J. Gastroenterol, vol.15, pp.137380, 2009.

[25]A.K.Kumar and K.Vijayalakshmi, Protective effect of Punica granatum peel and Vitis vinifera seeds on DEN-induced oxidative stress and hepatocellular damage in rats. Applied biochemistry and biotechnology, vol.175(1), pp.410-420, 2015.

[26]T.H.Chiu, K.Y.Lan, M.D.Yang, J.J.Lin, T.C.Hsia, C.T.Wu, J.S.Yang, F.S.Chueh, and J.G.Chung, Diallyl sulfide promotes cell-cycle arrest through the p53 expression and triggers induction of apoptosis via caspase- and mitochondria-dependent signaling pathways in human cervical cancer Ca Ski cells. Nutr. Cancer; vol.65(3), pp.505-14, 2013.

[27]K.U.Ravi, Garlic: a source of herbal medicines for cancer therapy World. Journal of Pharmaceutical Research, vol.5(4), pp.17941838, 2016.

[28]A.Malki, M.El-Saadani and A.S.Sultan Garlic constituent diallyl trisulfide induced apoptosis in MCF7 human breast cancer cells. Cancer Biol. Ther., vol.8(22), pp.2175-85, 2009.

[29]YC and Z.Zhong, S-allylmercaptocysteine effectively inhibits the proliferation of colorectal cancer cells under in vitro and in vivo conditions". Cancer Lett., vol.310(1), pp.69-76, 2011.

[30]A.Herman-Antosiewicz, and S.V.Singh, Signal transduction pathways leading to cell cycle arrest and apoptosis induction in cancer cells by Allium vegetable-derived organosulfur compounds: a review. Mutation Research/Fundamental and Molecular Mechanisms of Mutagenesis, vol.555(1), pp.121-131, 2004. 